\title{
Testing price leadership role in major regional maize markets in Ethiopia: implications for targeted market intervention
}

\author{
Mesay Yami $^{1 *}$, Ferdi Meyer ${ }^{2}$ and Rashid Hassan ${ }^{3}$ \\ 1 Department of Agricultural Economics, Extension \& Rural Development, University of Pretoria, South \\ Africa; \\ ${ }^{2}$ Bureau for Food and Agricultural Policy (BFAP), University of Pretoria, South Africa; \\ ${ }^{3}$ Centre for Environmental Economics and Policy Analysis (CEEPA), University of Pretoria, South Africa. \\ * Corresponding author Email: mesay44@gmail.com
}

\begin{abstract}
The central market hypothesis or price leadership role is an important concept of market integration, and it has relevant policy implications because it simplifies market price monitoring and intervention in the grain market. Knowledge about the presence of a central market and its price dynamic effects on satellite markets will assist the effectiveness of food assistance and other humanitarian food price support interventions. This is of particular interest to constant food aid recipients such as Ethiopia. This article intends to empirically investigate as to whether or not there is a central maize market that dictate and lead price information flow over the regional wholesale maize markets in Ethiopia. If such dominant maize market exists, then how does its price affect the maize grain prices of major regional wholesale maize markets in Ethiopia? The extended VAR procedure of Toda and Yamamoto Granger Causality approach is used to test the central maize market hypothesis. Furthermore, we use the system of seemingly unrelated regression model to examine the effects of the central market price on three wholesale regional maize market prices in Ethiopia. The results indicate that Addis Ababa wholesale maize market influences the maize price formation of all regional maize markets examined in this study. Therefore, interventions targeting the central wholesale market could successfully provide a buffer for local maize surplus and consumption markets against undesirable price shocks stemming from the central market.
\end{abstract}

Keywords: Central market; Granger Causality; Maize; Price shocks; Price stabilisation 


\section{Introduction}

Recently, the Ethiopian grain markets have been characterised by price spikes. The food price inflation steadily increased from a mere 3 percent in 2002 to 28 percent in 2003 and rose further to 60 percent in 2008. After showing signs of stabilisation and decline in 2009 and 2010, the inflation kicked in once again and the yearly food inflation rate reached 39 percent and 28 percent in 2011 and 2012, respectively (Figure 1). This is a worrying situation for the Ethiopian government as the share of household food consumption expenditure (60 percent) dominates the food basket (CSA, 2015).

There is no consensus on the causes of high food price inflation in Ethiopia. In general, two schools of thought dominate the debates about the root causes of soaring food prices in Ethiopia. The first school of thought leans towards the policy of government to restrict foreign exchange for private traders as the main cause of cereal price swings in Ethiopia (Dorosh \& Ahmed, 2009; Admassie, 2013). The second school of thought argues that international price shocks are the main reasons for the domestic commodity price run-up (Conforti, 2004; Loening et al., 2009; Kelbore, 2013).

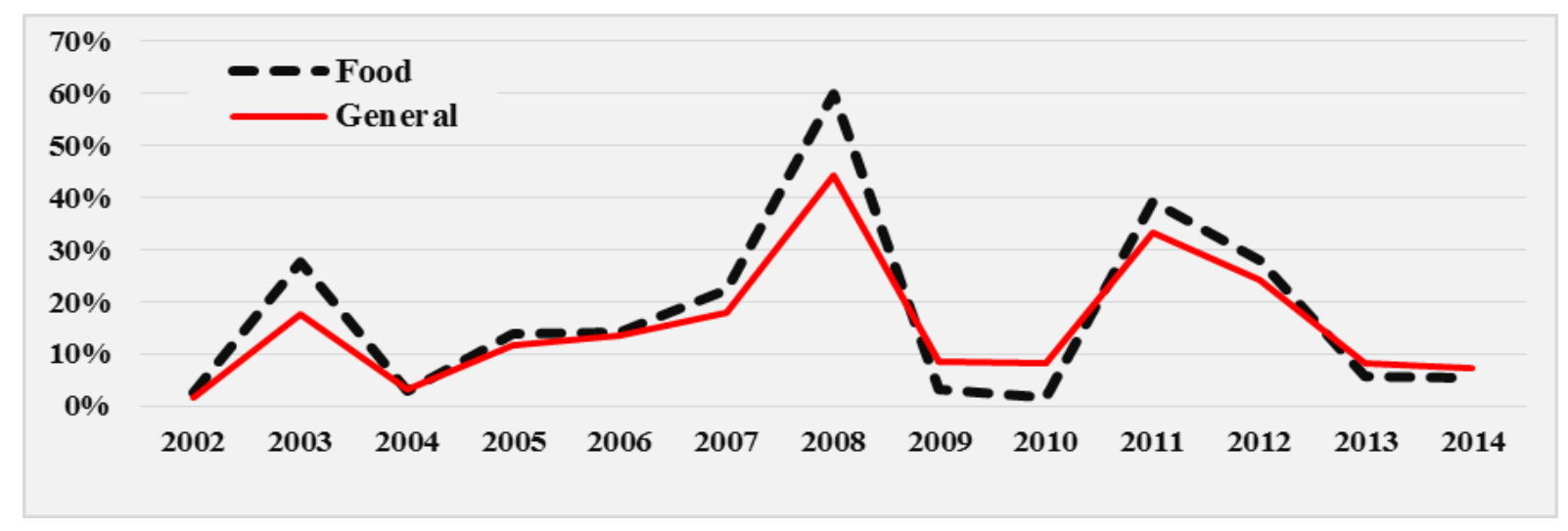

Figure 1: Inflation in Ethiopia (2001=100): year on year changes, (2001-2014)

Source: FAO (2015)

Compared to the prices of other major food crops, maize prices have historically been more volatile in Ethiopia. For example, maize prices collapsed considerably whenever there are bumper harvests as was the case in 1995/96, 1996/97, 1999/00, and 2001/02 (RATES, 2003). Maize prices collapsed by almost 80 percent and reached the lowest level in early 2002 . Bumper harvests led to the significant price drop and created market glut in higher producing 
areas. The aftermath of this catastrophe was widespread since the crop is produced on the largest smallholder coverage of 8.6 million farm households (CSA, 2015). The lesson learned by government, as well as international and national research organisations concerning the unprecedented low maize price episode of 2002 was that crop productivity improvement alone does not translate into welfare gains of producers. Therefore, agricultural policies that target farmers' livelihood improvement through technology adoption and crop productivity should go hand in hand with market development.

Since 2007, the real maize prices have shown an upward trend in the domestic market and reached close to US\$ 600/ton in September 2008 (Appendix Figure 1). Following the sharp rise in domestic grain prices in 2008, the Ethiopian government introduced different policy instruments to contain the soaring food prices. After the adoption of market liberalisation, the government for the first time have become heavily involved in commercial wheat imports. As a form of domestic supply stabilisation policy, the Ethiopian government additionally imposed an indefinite export ban on major cereal crops including maize, sorghum, teff, and wheat. Moreover, the government rationed the imported wheat to poor urban consumers at subsidised prices, and launched the largest productive safety net programme in the rural areas of Ethiopia. The two new policy instruments that proved the Ethiopian government's commitment to long-term grain price stabilisation were: (1) the introduction of weather index insurance in drought prone crop producing areas; and (2) establishment of the Ethiopia Commodity Exchange (ECX). These interventions have largely been praised for reducing production risks and bringing transparency in the grain market. However, these programmes are still in the early stages and their role with regards to grain price stabilisation is limited. For instance, ECX commenced its activity in April 2008. Since then, trading has been limited to high value exportable crops like coffee, sesame, and white beans.

In an agrarian based economy like Ethiopia, devising and implementing grain market price stabilisation policy is always a challenge for the government from two points of view. Firstly, unplanned price stabilisation intervention such as food aid distribution at times of high domestic crop production may depress domestic grain prices (Tadesse \& Shively, 2009). Secondly, grain market price stabilisation polices typically consume huge amount of government budget. For instance, following the involvement of the Ethiopian government in commercial wheat imports in 2008, the total wheat import bills of the country rose by 318 
percent from US\$ 192 million to US\$ 803 million as compared to 2007 (UN comtrade, 2015).

One way of optimising the policy cost of market intervention is through targeted grain market intervention; by focusing on the central grain market that lead and dictate the price formation and information flow over the regional grain markets (Getnet et al., 2005). Market intervention programs should prove efficiency and effectiveness in order to be sustainable and successful. According to Getnet et al., (2005), government intervention at the central market would be less costly and effective in comparison to interventions at other market levels. Since the central market function is a major demand centre, demand creating interventions can be implemented more effectively.

Efficient integrated grain markets reduce food insecurity and price spikes, by allowing efficient reallocation of produce from surplus to deficit areas. As a result, prices in deficit markets will be stabilised, and producers in surplus markets will get the right price for their produce, which further promote production specialisation. Nevertheless, market integration is only a necessary but not a sufficient condition to guarantee food security and better producer prices (Getnet et al., 2005). To further strengthen the price transmission role of integrated markets, government intervention, even in integrated markets may be desirable when markets fail to stabilise market prices (Smith, 1997; Getnet et al., 2005). Smith (1997) highlights the need for government intervention to achieve adequate stability as a result of several compelling instances to do so even in well-functioning markets. This is advisable typically during unprecedented food price spikes and bumper crop years that will erode consumers' purchasing power and discourage farmers from using modern production techniques in the face of low output prices.

The central market hypothesis or price leadership role is an important concept of market integration, and it has relevant policy implications, especially for developing countries (Ravallion, 1986). The existence of a central market makes it easier for governments to monitor and intervene price distortion in the grain markets. Thus, further reduces the costs of grain price stabilisation policy (Sadoulet \& Janvry, 1995). Knowledge about the presence of a central market and its price dynamic effects on the regional or satellite markets will assist the effectiveness of food assistance and other humanitarian food price support interventions. This will be done by either targeting the central market or satellite grain markets that are 
exposed to price shocks stemming from the central market (Asche et al., 2012). This is of particular interest to constant food aid recipients such as Ethiopia ${ }^{1}$.

Literature on spatial grain market integration in Ethiopia relied on the traditional Granger Causality test to draw conclusion about the lead-lag price relationships among regional grain markets (Getnet et al., 2005; Jaleta \& Gebremedhin, 2009; Ulimwengu et al., 2009; Rashid, 2011; Kelbore, 2013; Tamru, 2013). However, the traditional causality test is often criticised because of the sensitivity of the test for stationarity and co-integration relationships (Mavrotas \& Kelly, 2001). As proven by Perron (1989), the traditional unit root test in the presence of a structural break is biased towards the non-rejection of the null hypothesis of non-stationarity. This in turn has consequences on co-integration, the specification of Vector Autoregression (VAR), and the results of Granger Causality tests. The sudden rise in domestic maize prices in mid-2008 and the policy reforms made by the Ethiopian government are expected to shift the properties of grain prices either abruptly or gradually. Under these conditions, relying on the results of the traditional unit root test is quite perilous. Against this backdrop, this study avoids the pre-testing biases for unit root tests and cointegration by employing the causality test of Toda and Yamamoto (1995) extended VAR procedure that can be applied irrespective of the order of integration and co-integration of the series.

This article intends to empirically investigate as to whether or not there is a central maize market that dictates and lead price information flow over the regional maize markets in Ethiopia. If such dominant maize market exists, then how does its price affect the maize grain prices of major regional wholesale maize markets in Ethiopia? This study relied on monthly wholesale maize grain prices from four market locations for the period 2000 M1 to 2015 M3. Maize crop is selected for this study because of two reasons. First, owing to the strategic importance of maize for food security in Ethiopia, government and Nongovernmental organisations (NGOs) interventions have been more pronounced on maize crop. Second, following the highest productivity and largest number of growers, instability on maize price is also expected to translate into market price instability of other tradable

\footnotetext{
${ }^{1}$ Food aid was the major source of grain imports for Ethiopia until 2007. Between 2001 and 2007, 57 percent of the average imported wheat by Ethiopia was food aid. The remainder 43 percent was commercial wheat imports by private traders. However, from 2008 onwards, commercial imports have become the main source of wheat import. In 2013, Ethiopia imported 1.9 million tons of wheat; commercial import constituted 90 percent, while the remainder 10 percent was food aid (UN comtrade, 2015).
} 
food crops such as wheat and sorghum. Studies by Getnet (2009) and Rashid (2011) reinforce the choice of maize crop for this study. Both studies concluded that common stabilisation strategies targeting maize commodity instead of localised strategies targeting different commodities would optimise the policy costs of grain price stabilisation in Ethiopia.

The rest of the article is organised as follows. Section two discusses maize production and productivity trends in Ethiopia. Section three describes the data source and analysis approaches. Section four presents the results of the study. Section five concludes and outlines possible policy options to improve the performance of maize industry in Ethiopia.

\section{Overview of maize production in Ethiopia}

Maize is Ethiopia's largest cereal commodity in terms of total production and number of producers. About 8.6 million smallholder farmers cultivate maize, while 5.4 million produce Teff, and 4.1 million farmers produce wheat. Smallholder farmers predominantly dominate maize production. Smallholder farmers with average land holdings of $<1$ ha supply about 95 percent of maize production. The remainder 5 percent is supplied by commercial and state farms (CSA, 2015).

Maize is an important staple food crop in Ethiopia. It accounts 17 percent of the per capita calorie intake, followed by sorghum (14 percent), and teff (11 percent). Maize dominates rural consumption baskets, with 436 per capita calories, compared to only 107 per capita calories in urban areas (Berhane et al., 2011).

Maize production is concentrated primarily in two regions in Ethiopia. These regions are Amhara and Oromia, and they account for about 82 percent of the national maize production (Rashid \& Minot, 2010). Most farmers produce maize during the long rainy season that is from May to September. A small amount is produced in the short rainy period, from February to May. Farmers in the western region plant maize using the residual moisture in January and harvest in June/July (Worku et al., 2001). During 2001-2006 and 2012-2015, on average, maize production registered a 113 percent growth rate from 2.8 million $\mathrm{mt}$ to 6.1 million $\mathrm{mt}$ (Table 1). Maize production reached 6 million tons in 2015 (USDA, 2015). 
Ethiopia has registered tremendous growth in boosting maize yield. A five-year average of maize yield between 2011 and 2015 was estimated at 2.94 tons/ha (USDA, 2015). Maize yield reached a peak level of 3.25 tons/ha in 2013. South Africa and Ethiopia are the only countries in Sub Saharan Africa (SSA) that have attained $>3$ tons/ha on maize yield. Only Zambia and Uganda have managed to reach $>2.5$ tons/ha, followed by Malawi with $>2$ tons/ha. Ethiopia is ranked fifth in terms of area devoted for maize production in SSA, but is second only to South Africa in yield and third after South Africa and Nigeria in production (Abate et al., 2015). The maize Self-Sufficiency Ratio (SSR) ${ }^{2}$ indicates that the country has been largely self-sufficient on maize production. The SSR for maize has been fluctuating between 94 percent and 102 percent implying that the country is trading in an autarky trade regime ${ }^{3}$.

Table 1: Average change in production and consumption of major food crops in Ethiopia (1995-2003 to 2004-2015)

\begin{tabular}{|c|c|c|c|c|c|c|c|}
\hline \multirow{2}{*}{ Crops } & \multicolumn{3}{|c|}{ Avg. production ('000 tons) } & \multicolumn{3}{|c|}{ Avg. total consumption ('000 tons) } & \multirow{2}{*}{$\begin{array}{l}\text { Trade } \\
\text { regimes }\end{array}$} \\
\hline & $1995-2003$ & 2004-2015 & $\% \Delta$ & 1995-2003 & 2004-2015 & $\% \Delta$ & \\
\hline Wheat & 1,629 & 3,056 & 88 & 2,224 & 3,857 & 73 & IPP* \\
\hline Maize & 2,637 & 4,886 & 85 & 2,632 & 4,849 & 84 & Autarky \\
\hline Sorghum & 1,572 & 3,157 & 101 & 1,601 & 3,160 & 97 & Autarky \\
\hline Millet & 359 & 595 & 66 & 359 & 592 & 65 & Autarky \\
\hline
\end{tabular}

*IPP denotes Import Parity Price

Source: Author's calculation using USDA data (2015)

\section{Econometric framework}

The econometric approach the study rely on to examine the effects of the central wholesale maize price on the regional maize markets is the Seemingly Unrelated Regression (SUR)

\footnotetext{
${ }^{2}$ SSR is calculated as the ratio of domestic production to (production plus import minus exports).

${ }^{3}$ Depending on the country's production and consumption growth, commodity price formation depends on either of the three trade regimes: autarky, Import Parity Price (IPP) or Export Parity Price (EPP). If a country is a net importer of a commodity, then the price formation depends on the IPP. The domestic price should then be a function of world price, exchange rates, transportation costs, and possible import tax. In this trade regime, one would expect a high degree of price transmission from world to domestic market. On the other hand, if a country is a net exporter of a commodity, then the trade regime switches to EPP. Under this condition, the extent of price shocks transmission from world to domestic market become high. However, when a country reaches a self-sufficient position, domestic price formation lies within the price band of IPP and EPP. In an autarky trade regime, domestic price is determined by the interaction of domestic supply and demand conditions and is unrelated to international price shocks (Meyer et al., 2006).

${ }^{4}$ Total consumption includes household food consumption, seed, and industrial use. It is based on USDA and CSA classification of grain use in Ethiopia.
} 
model. SUR approach is more efficient than OLS because it controls for the contemporaneous correlation of unobserved shocks across markets (Tadesse \& Shively, 2009).

The vector representation of SUR model incorporating exogenous and shift variable is specified as follows:

$$
p_{t}=\alpha_{0}+\psi_{1} p_{t-1}+\psi_{2} p_{t-2}+\cdots+\psi_{p} p_{t-p}+\Phi D_{t}+\Theta x_{t}+\varepsilon_{\mathrm{t}}
$$

where P indicates an $n \times 1$ vector of regional, satellite or dependent wholesale maize market prices; $\psi$ is an $n \times k$ matrix of autoregressive coefficients for the lagged satellite and central maize market prices; $k$ is the lag length selected using information criteria; $x_{t}$ is exogenous variables including demand and supply shifters such as population and monthly rainfall of regional maize markets. Conditional on the Toda and Yamamoto (1995) granger causality test, the contemporaneous and lagged prices of the central wholesale maize price will be treated as exogenous; $\Phi$ and $\Theta$ are parametric matrices; and $D_{t}$ represents an $\left(\begin{array}{lll}1 & \mathrm{x} & 1\end{array}\right)$ matrix of deterministic component. $D_{t}=\left\{\begin{array}{ll}1, & \mathrm{~T}_{0} \\ 0, & \text { Otherwise }\end{array}\right.$ is the shift variable to account for the sharp rise in domestic maize market prices. During January 2008 to October 2009, the domestic maize prices increased markedly. Therefore, $T_{0}$ is the date from which the domestic maize prices rose sharply.

The $n x 1$ vector $\varepsilon_{t}$ is a vector of generalisation of white noise, that is,

$$
E\left(\varepsilon_{t}\right)=0 \text { and } E\left(\varepsilon_{t} \varepsilon_{\tau}\right)=\left\{\begin{array}{l}
\Omega \text { for } t=\tau, \\
0 \text { otherwise }
\end{array}\right.
$$

Of particular interest to this study are the signs, magnitudes, and statistical significance of the exogenous variable $x_{t}$ consisting of the marginal impacts of the central wholesale maize prices on contemporaneous satellite or dependent maize market prices. Consistent and efficient estimates of the parameters of equation (1) are obtained using Iterated Feasible Generalized Least Squares (IFGLS), which is equivalent to maximum likelihood estimation. Efficiency in IFGLS requires stationarity and the absence of serial autocorrelation (Tadesse \& Shively, 2009). Unit root is tested using Augmented Dickey Fuller (ADF) regression as proposed by Dickey and Fuller (1979). For robustness, the Phillips-Perron (PP) and Kwiatkowski-Phillips-Schmidt-Shin (KPSS) test are also estimated (Table 3). All the maize 
market price series are $I$ (1). Serial correlation tests are conducted using the Breusch-Godfrey LM test.

Toda and Yamamoto (1995) (From now on T-Y) Granger Causality approach is used to empirically investigate the presence of a central maize market. The novelty of T-Y approach is that first, unlike the conventional Granger Causality test, the researcher does not bother for the order of integration and co-integration. You can estimate the VAR in level form and evaluate the relationships between variables using the modified Wald (MWALD) test. Thus, avoids the potential pre-test biases associated with unit roots and co-integration tests (Zapata \& Rambaldi 1997; Clarke \& Mirza 2006). Second, it proposes a causality testing in a possibly integrated and co-integrated system using an augmented level VAR modelling that gives allowance for the long-run information. Third, inference from the MWALD test is valid as long as the order of integration of the process does not exceed the true lag length of the model (Toda \& Yamamoto, 1995).

T-Y suggested that researchers could estimate a $\left(K+d_{\max }\right)^{\text {th }}$ order VAR. Therefore, prior to estimating the T-Y causality test, the test for the order of integration and lag length selection criteria are the precondition to test the maximal order of integration $\left(d_{\max }\right)$ and the true optimum lag length $(K)$. To this end, optimum lag length is selected using Akaike Information Criterion (AIC), adjusted Likelihood Ratio (LR), and Final Prediction Error (FPE) tests.

A VAR $(p)$ in a compact form is given as:

$$
Y_{t}=C+\phi_{1} Y_{t-1}+\phi_{2} Y_{t-2}+\cdots+\phi_{p} Y_{t-p}+\varepsilon_{t}
$$

where is $n \times 1$ vector, C is $n \times 1$ vector of constants, $\Phi_{j}$ is $n \times n$ matrix of autoregressive coefficients, i.e. $\mathrm{j}=1,2, \ldots P, \varepsilon_{t}$ is $n \times 1$ vector of generalisation of white noise, where $E\left(\varepsilon_{t}\right)=0$ and $E\left(\varepsilon_{t} \varepsilon_{\tau}\right)=\left\{\begin{array}{l}\Omega \text { for } t=\tau, \\ 0 \text { otherwise }\end{array}\right.$

In this study, T-Y causality test of VAR $\left(K+d_{\max }\right)$ for the four maize market prices can be specified as:

$$
\begin{gathered}
y_{t}=a_{0}+\sum_{i=1}^{p=k+d(\max )} \Phi_{i} y_{t-i}+u_{t} \\
y_{t}=\left[\begin{array}{c}
\text { Addis }_{t} \\
\text { Mekele }_{t} \\
\text { Dire } t_{t} \\
\text { Bahir }_{t}
\end{array}\right] \quad a_{0}=\left[\begin{array}{c}
\alpha_{1} \\
\alpha_{2} \\
\alpha_{3} \\
\alpha_{4}
\end{array}\right] \quad \Phi_{i}=\left[\begin{array}{l}
A_{11, i} A_{12, i} A_{13, i} A_{14, i} \\
A_{21, i} A_{22, i} A_{23, i} A_{24, i} \\
A_{31, i} A_{32} A_{33, i} A_{34, i} \\
A_{41, i} A_{42 i} A_{43, i} A_{44 i}
\end{array}\right] \quad y_{t-i}=\left[\begin{array}{c}
\text { Addis }_{t-i} \\
\text { Mekele }_{t-i} \\
\text { Dire }_{t-i} \\
\text { Bahir }_{t-i}
\end{array}\right] \quad u_{t}=\left[\begin{array}{c}
\varepsilon_{1 t} \\
\varepsilon_{2 t} \\
\varepsilon_{3 t} \\
\varepsilon_{4 t}
\end{array}\right]
\end{gathered}
$$


where, ' $d$ ' is the first order difference operator. The order of $p$ represents $\left(k+d_{\max }\right)$ and $y_{t-i}$ denotes lagged maize prices in the study markets. Direction of causality can be confirmed by applying the standard Wald test to the first ' $K$ ' VAR coefficient matrix. For example, in

the first equation $\mathrm{H}_{0}: A_{12,1}=A_{12,2}=\cdots=A_{12, k}=0$, implies that Mek'ele price does not granger cause Addis Ababa maize price, and $\mathrm{H}_{0}: A_{21,1}=A_{21,2}=\cdots=A_{21, k}=0$, implies that Addis Ababa wholesale maize price does not granger cause Mek'ele maize prices and so on.

\subsection{Data}

The study relied on data obtained from different sources including FAO, the Central Statistical Agency of Ethiopia (CSA), and National Meteorological Agency of Ethiopia (NMA). Monthly wholesale maize market prices originating from four market locations in Ethiopia namely Addis Ababa, Bahir Dar, Dire Dawa, and Mek'ele maize markets were used for this study. The time span of the monthly price series covers from January 2000 to March 2015. To account for inflationary influence, the nominal prices were deflated by the Consumer Price Index (CPI). All the maize price series were converted into natural logarithms.

The regional maize markets price trends are plotted in Figure 2. It is clear that in 2008 the domestic wholesale maize prices rose sharply in all markets. From the visual observation from the graph, the nominal maize prices for Mek'ele and Dire Dawa markets have been consistently higher than Addis Ababa maize market prices. Higher maize price can be attributed to the supply deficiencies in the two markets. In addition, the two markets are located relatively farther away from Addis Ababa market. Mek'ele market is located in the Northern part of Ethiopia. The driving distance between Mek'ele and Addis Ababa is 762 $\mathrm{km}$. While the nearest market is the Eastern market of Dire Dawa, which is located at the distance of $446 \mathrm{~km}$ from Addis Ababa. The North-West market of Bahir Dar is found at the radius of $521 \mathrm{~km}$ to Addis Ababa market. Higher maize price therefore may have something to do with the isolation and deficiencies of maize production in these two markets. 


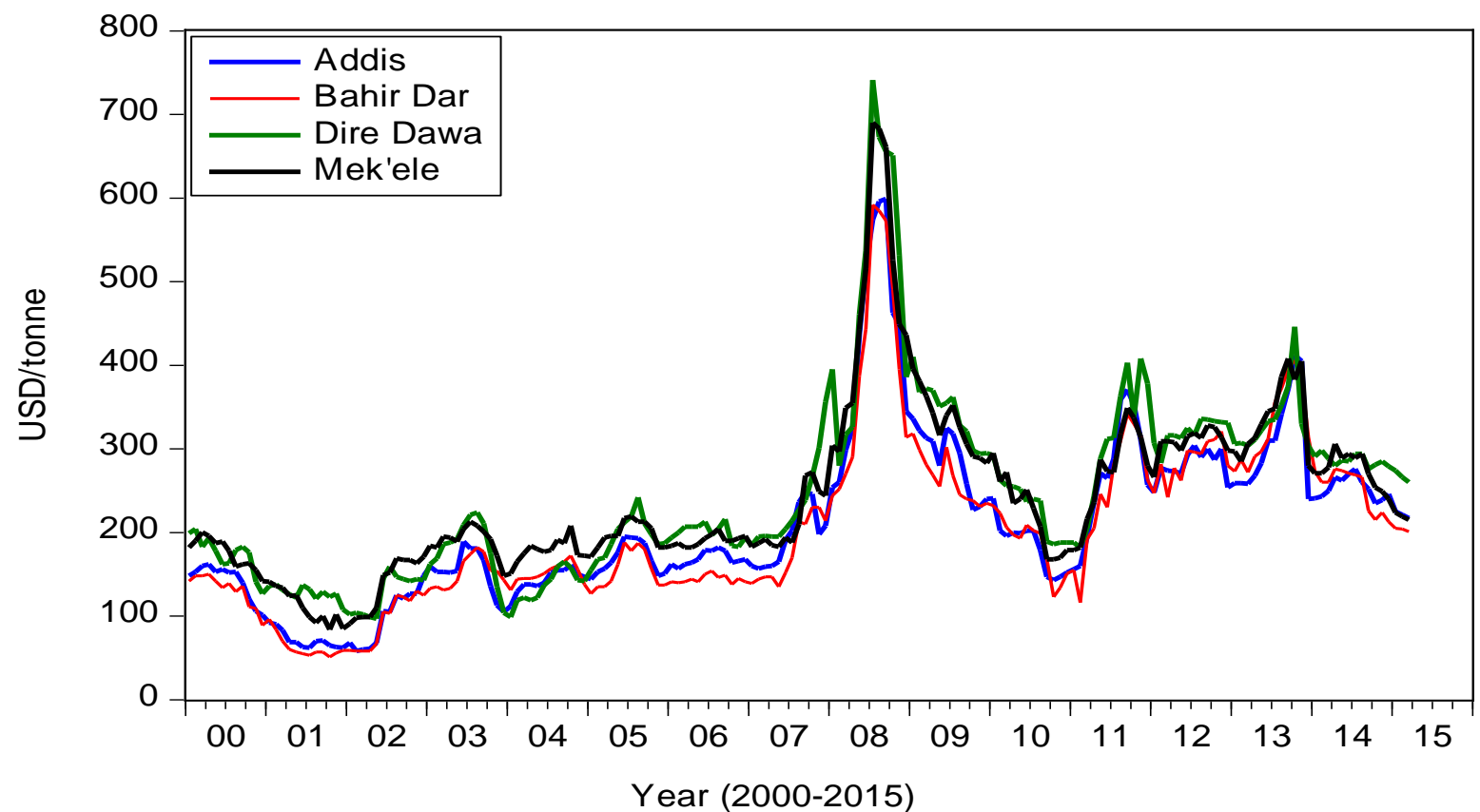

Figure 2: Nominal wholesale maize prices in four maize market places in Ethiopia (2000:01- 2015:03)

The descriptive results for the wholesale maize prices are presented in Table 2. Higher mean maize prices were observed in the two maize deficit markets of Dire Dawa and Mek'ele, while the lowest was at Bahir Dar. The maximum maize price was obtained in Dire Dawa followed by Mek'ele. The lowest prices was noticed in surplus producing regions of Bahir Dar. Variation of maize prices reveals that Bahir Dar market has more variation than the rest maize markets. This variation on maize prices can be attributed to the seasonality of maize production in main producing regions, where prices typically decline at harvesting time and start to swing upwards during lean months.

Table 2: Descriptive results of the nominal wholesale maize market prices

\begin{tabular}{lcccc}
\hline Statistics & Log (Addis) & Log (Bahir Dar) & Log (Dire Dawa) & Log (Mek'ele ) \\
\hline Mean & 5.24 & 5.19 & 5.42 & 5.41 \\
Median & 5.23 & 5.18 & 5.36 & 5.34 \\
Maximum & 6.39 & 6.38 & 6.61 & 6.54 \\
Minimum & 4.06 & 3.93 & 4.57 & 4.43 \\
Coef. Var (CV) & 0.09 & 0.1 & 0.08 & 0.07 \\
Skewness & -0.35 & -0.42 & 0.16 & 0.05 \\
Kurtosis & 3.20 & 3.23 & 2.74 & 3.39 \\
Observations & 183 & 183 & 183 & 183 \\
\hline
\end{tabular}




\section{Empirical results}

\subsection{Maize price leadership role}

Before commencing the estimation of T-Y causality test, one must identify the maximum order of integration $\left(d_{\max }\right)$ of the underlying variables as well as the optimal lag length $(k)$ of the VAR system. To address this, Dickey and Fuller (1979) proposed a test to detect the nonstationarity of series using the Augmented Dickey-Fuller test (ADF). Table 3 depicts the results of unit root tests based on $\mathrm{ADF}^{5}$, PP, and KPSS statistics on levels and first difference of the variables. The null hypothesis of $\mathrm{ADF}$ and PP test is that the variable has a unit root (non-stationary). On the other hand, KPSS test is the reverse of the two tests (the variable is stationary against the alternative of a unit root). Thus, KPSS test is used to complement and substantiate the results of ADF and PP tests. The results of all unit root tests correspond with each other. They reveal that all series are $I$ (1). Therefore, the maximum order of integration is one. On the basis of the information criterion (AIC, LR, and FPE), the optimal lag length of the VAR in equation (3) is selected as two. Thus, supporting the validity of the T-Y approach of granger causality test, as the true lag length of the model is greater than the order of integration. In the next stage, we augment the VAR by the maximum order of integration of the series $\left(d_{\max }\right)$ and estimate VAR (3). Model adequacy tests ${ }^{6}$ for the residual series approved the robustness of the specification.

Table 3: Unit root tests

\begin{tabular}{llll}
\hline & ADF & PP & KPSS \\
\hline Level (constant, no trend) & & & \\
\hline Addis Ababa & -2.31 & -1.84 & $0.98^{* * *}$ \\
Bahir Dar & -2.30 & -1.85 & $0.99^{* * *}$ \\
Dire Dawa & -2.02 & -1.86 & $0.98^{* * *}$ \\
Mek'ele & -2.28 & -1.98 & $0.89 * * *$ \\
\hline First difference (constant, no trend) & & & \\
\hline Addis Ababa & $-3.17^{* *}$ & $-9.82^{* * *}$ & 0.058 \\
Bahir Dar & $-3.24^{* *}$ & $-11.89^{* * *}$ & 0.061 \\
Dire Dawa & $-3.42^{* *}$ & $-10.83^{* * *}$ & 0.062 \\
Mek'ele & $-3.42^{* *}$ & $-11.77^{* * *}$ & 0.065 \\
\hline
\end{tabular}

$* * *, * *$ reject the null of unit root at 1 and $5 \%$ significance level

${ }^{5}$ Unit root test was estimated following the procedures proposed by Doldado et al, (1990). The ADF test equation having random walk with drift is specified as $\Delta \gamma_{t}=\alpha+\delta \gamma_{t-1}+\sum_{i=1}^{\rho} \beta_{i} \Delta \gamma_{t-i}+u_{t}$.

${ }^{6}$ Diagnostics test was made using the Breusch-Godfrey (1978) test of serial correlation. The BG(2)-test has a $p$-value of $38.11 \%$, so the test failed to reject the null of no serial correlation against the alternative of second order autocorrelation. 
Table 4 presents the result of T-Y modified Wald test of causality between wholesale maize markets in Ethiopia. The findings indicate that Addis Ababa wholesale maize market price movements affect the maize prices of both deficit (Mek'ele and Dire Dawa) and surplus (Bahir Dar) regional wholesale maize markets. The null hypothesis of no causality from the Addis Ababa maize price to all regional maize markets has been rejected. The direction of causation is one-way from Addis Ababa price to the rest regional maize markets. The converse, however, does not hold. The non-causality in the opposite direction implies that Addis Ababa maize price is exogenous and is not impacted by any single regional maize market considered in this study. Thus, Addis Ababa's wholesale maize market is behaving like a dominant maize market in Ethiopia. The price movements of regional maize markets are dictated by the Addis Ababa maize market. This concurs with the notion of the Ravallion (1986) dominant-satellite market price relationships. The geographical advantage enables Addis Ababa wholesale maize market to have large number of feeder markets, which further contributes to unidirectional price influence.

Table 4: Modified Wald test (MWALD) of T-Y causality test

\begin{tabular}{lcccc}
\hline Maize markets & Addis & Bahir Dar & Dire Dawa & Mek'ele \\
\hline Addis Ababa & & $16.44^{*}$ & $15.00^{*}$ & $19.58^{*}$ \\
& & $(0.000)$ & $(0.000)$ & $(0.000)$ \\
Bahir Dar & 2.78 & & 1.21 & 2.19 \\
& $(0.24)$ & & $(0.54)$ & $(0.33)$ \\
Dire Dawa & 1.98 & 0.56 & & 2.28 \\
& $(0.37)$ & $(0.75)$ & & $(0.31)$ \\
Mek'ele & 3.14 & 2.71 & 4.22 & \\
\hline
\end{tabular}

Null hypothesis of non-causality: $\chi^{2}(2)$ statistics

Probability values in parenthesis;*rejection of the null of no causality

\subsection{Effects of central maize price on regional markets}

Given the initial aim of examining the impact of central wholesale maize price on the regional maize market price, the information derived from T-Y Granger Causality does not suffice. Detecting causality is useful in answering the exogeneity and endogeneity of the dependent variable within the specified sample period. The test, however, is unable to provide the magnitude of influence of Addis Ababa wholesale maize price on the regional maize prices. In this study, the contemporaneous and lagged impacts of central wholesale maize prices on regional maize prices were estimated using SUR. Results for the regression output is presented in Table 5. 
The contemporaneous increase on monthly maize price in Addis Ababa wholesale market has significantly influenced all the regional maize markets. The influence was most pronounced on the surplus Bahir Dar maize market price. On average, a 1 percent increase in the contemporaneous Addis Ababa monthly wholesale maize price leads to 0.7 percent rise in monthly wholesale maize price of Bahir Dar market. While it raises the maize prices of Mek'ele and Dire Dawa maize market by 0.57 percent and 0.47 percent, respectively. Comparison across markets indicates that prices in Bahir Dar and Mek'ele seem more correlated with the central market than Dire Dawa maize market. It is worthwhile to mention that the regions where these two markets are located namely Amhara and Tigray regions, spend more proportion of their income for the consumption of maize than Dire Dawa region. On average, consumers in Amhara and Tigray regions spend 5.3 percent and 2.7 percent of their cereal food expenditure on maize. On the other hand, only 0.7 percent of food expenditure is allocated for maize consumption in Dire Dawa (Berhane et al., 2011).

The estimated contemporaneous price transmission elasticities for this study $(0.70,0.57$, and 0.47) are somewhat lower than the previous results obtained by Dercon (1995) in postmarket liberalisation period in Ethiopia (0.70, for the period after peace [1991M6 until 1993M9]). However, it is higher than the results obtained by Getnet et al., (2005) ${ }^{7}$, (0.36 for a spatial price transmission between local market and the central market in Ethiopia). We would thus conclude that, overtime the magnitude of influence of the central market prices on the regional wholesale market prices in Ethiopia has been increasing. Therefore, interventions targeting the central wholesale market could successfully provide a buffer for local maize surplus and consumption markets against undesirable price shocks stemming from the central market.

\footnotetext{
${ }^{7}$ Getnet et al., (2005) examine the spatial price integration between the central wholesale and local producer prices of white teff in Ambo market in Ethiopia. The focus of their study is different from the present study in terms of the type of crop, nature of market integration, and market location. It is therefore important to keep in mind that their results are only mentioned for the sake of comparison.
} 
Table 5: Seemingly Unrelated Regression results of Addis Ababa maize price on regional wholesale maize prices

\begin{tabular}{|c|c|c|c|c|c|c|}
\hline \multirow[b]{2}{*}{ Variables } & \multicolumn{2}{|c|}{ Bahir Dar } & \multicolumn{2}{|c|}{ Mek'ele } & \multicolumn{2}{|c|}{ Dire Dawa } \\
\hline & Coefficient & Std. Error & Coefficient & Std. Error & Coefficient & Std. Error \\
\hline Addis price & 0.7014 & $0.056^{* * *}$ & 0.572 & $0.042^{* * *}$ & 0.471 & $0.065 * * *$ \\
\hline Addis price ${ }_{t-1}$ & 0.3863 & $0.074^{* * *}$ & 0.353 & $0.061^{* * *}$ & 0.295 & $0.074 * * *$ \\
\hline $\mathrm{R}^{2}$ & \multicolumn{2}{|c|}{0.57} & \multicolumn{2}{|c|}{0.61} & \multicolumn{2}{|c|}{0.34} \\
\hline Adjusted $\mathrm{R}^{2}$ & \multicolumn{2}{|c|}{0.55} & \multicolumn{2}{|c|}{0.59} & \multicolumn{2}{|c|}{0.30} \\
\hline Observations & \multicolumn{2}{|c|}{179} & \multicolumn{2}{|c|}{179} & \multicolumn{2}{|c|}{178} \\
\hline Wald test $\left(\chi^{2}\right)$ & \multicolumn{2}{|c|}{$157.3^{* * *}$} & \multicolumn{2}{|c|}{$180.7^{* * *}$} & \multicolumn{2}{|c|}{$52.6^{* * *}$} \\
\hline
\end{tabular}

Note: *** at $1 \%$ significance level; For the sake of brevity, the coefficient estimates for other regressors such as lagged maize market prices, rainfall, population, and shift variable are not presented here, but full results are available on request. The Wald tests are for the null hypothesis of the effects of Addis Ababa maize price is zero across the regional wholesale maize markets. Serial correlation tests were conducted using the Breusch-Godfrey LM test. In order to whiten the residual, the test recommended three lags in the case of Bahir Dar and Mek'ele and four lags for Dire Dawa maize market regression.

In general, the current effects of Addis Ababa monthly maize price has higher impact on the regional maize prices than the lagged price. This could be attributed to improvement on the spatial market integration of regional maize markets with the central Addis Ababa market. Previous studies on the inter-regional spatial market integration in Ethiopia indicated that grain market integration has improved following the introduction of market liberalisation (Negassa \& Jayne, 1997; Negassa \& Myers, 2007; Tamru, 2013). This can be attributed to the aggressive move by the Ethiopian government in improving market fundamentals such as roads infrastructure, market institutions, and information communication service development. Agricultural production system in Ethiopia is characterised by widely dispersed production and consumption areas. Quality physical infrastructural development would therefore play a crucial role in food reallocations from major producing regions to deficit consumption areas. In view of this importance, the Ethiopian government has placed more emphasis on the development of market fundamentals since 1999. Especially, the progress in rural road development has been encouraging (ERA, 2015). Progress in road development coupled with shift from traditional to motorised transport has improved the timely mobility of agricultural products from surplus to deficit areas in Ethiopia (Minten et al., 2012). 
Market information can also influence spatial market integration and the magnitude and speed of price adjustment. Information communication services were largely inaccessible in Ethiopia in the 1990s. It was only less than one percent of the population (0.27 per 100 people) had access to fixed telephone service. Mobile services were also unavailable until 1999. However, from 2000 onwards, access to means of acquiring market information has rapidly expanded with the ease of access to mobile and landline services. Since 2000, mobile subscription has annually increased by 78 percent. Likewise, the fixed telephone subscription has been growing annually by 10 percent since 2000. Currently, 32 percent of Ethiopian population have access to mobile service (ICT, 2015). Although the telecommunication sector has been monopolised by the state, the recent development in the sector may positively contribute towards better market price information flow and regional grain market price integration.

The other possible explanation for higher price signals transmission among maize markets considered in this study is improvement in the grain market structure. After the introduction of market liberalisation in March 1990, there is strong evidence of improvement in competitiveness of the grain market structure in Ethiopia. During 2001-2011, the number of traders and brokers increased by 140 percent and 252 percent in the wholesale grain markets in Ethiopia (Minten et al., 2012). This could in turn facilitate spatial arbitrage operation to exploit profitable price difference from the long run equilibrium position.

\section{Conclusions and policy options}

The central market hypothesis or price leadership role is an important concept of market integration, and it has relevant policy implications because it simplifies market price monitoring and intervention in the grain market. Knowledge about the presence of a central market and its price dynamic effects on the satellite markets will assist the effectiveness of food assistance and other humanitarian food price support interventions. This will be done by either targeting the central market or satellite grain markets that are exposed to price shocks stemming from the central market. This is of particular interest to constant food aid recipients such as Ethiopia. This article employs the Toda and Yamamoto extended VAR procedure, to test the central market hypothesis on the wholesale maize markets in Ethiopia. Furthermore, we use the system of seemingly unrelated regression model to examine the effects of the central market price on regional wholesale maize market prices. The results 
indicated that the central (Addis Ababa) wholesale maize market influences maize price formation of all regional maize markets examined in this study. Thus, Addis Ababa maize price influences the information flow to the regional maize markets of Bahir Dar, Mek'ele, and Dire Dawa. The results support prior expectation that Addis Ababa wholesale maize market serves as an important hub for maize market, and more importantly as a hotspot for source of maize price shocks, which influence the short and long-run price fluctuations of regional wholesale maize market places.

The policy implications drawn from this study is that in order to cushion the effects of undesirable maize price shocks on consumers and producers, close monitoring of Addis Ababa maize price is critical. Since a central market such as Addis Ababa is mostly a consumption centre, demand creating intervention in the central market would improve the purchasing power of poor urban consumers. This can create demand for agricultural produce coming from producing regions. Such intervention would therefore enable wholesalers to find an outlet for their products and guarantee better prices to producers (provided that maize market operate in a perfectly competitive market with no presence of market power in the supply chain). Thus, will have positive effects on the welfare of both producers and consumers through price transmission process. Furthermore, there is a need to improve the food distribution system from the main maize feeder markets to Addis Ababa. Improving the market linkage through investment in road infrastructure can reduce the transaction costs, which can further improve the efficiency of maize production reallocations from surplus to the terminal Addis Ababa maize market. Finally, this study leaves room for further research to incorporate more consumption and surplus maize markets, to re-examine the analysis on the maize price leadership role and price dynamic effects of the central maize market in Ethiopia.

\section{Acknowledgements}

The authors gratefully acknowledge the financial support from Bureau for Food and Agricultural Policy (BFAP). The article has benefited from the constructive comments from Sean Kalundu, Bertha ljambo, and Ruthira Naraidoo. Earlier versions of this paper were presented at the $54^{\text {th }}$ Agricultural Economics Association of South Africa (AEASA). All errors remain our own 


\section{References}

Abate T, Bekele S, Abebe M, Dagne W, Yilma K, Kindie T, Menale K, Gezahegn B, Berhanu T, Tolera K. 2015. Factors that transformed maize productivity in Ethiopia. Food Sec. (2015) 7:965-981.

Admassie A. 2013. The political economy of food price: The case of Ethiopia. World Institute for Development Economic Research (WIDER) Working Paper No. 2013/001.

Asche F, GjØberg O, Guttormsen A. 2012. Testing the central market hypothesis: a multivariate analysis of Tanzanian sorghum markets. American Journal of Agricultural Economics. 43(2012):115-123.

Berhane G, Hodinott J, Kumar N, Taffesse A.S, Diresse M T, Yohannes Y, Sabates-Wheeler R, Handino M, Lind J, Tefera M, Feyera S. 2011. Evaluation of Ethiopia's Food Security Program: Documenting Progress in the Implementation of the Productive Safety Net Program and the Household Asset Building Program. International Food Policy Research Institute and Institute of Development Studies. Washington, D.C.

Breusch, T.S. (1978). Testing for autocorrelation in dynamic linear models. Australian Economic Papers, 17, 334-55.

Central Statistical Agency (CSA). 2015. Agricultural Sample Survey 2014/2015. Vol I. Report on area and production of major crops (private peasant holdings, Meher season).

Clarke JA, Mirza S. 2006. A Comparison of some common methods for detecting Granger noncausality. Journal of Statistical Computation and Simulation. 76 (3): 207-231.

Conforti P. 2004. Price transmission in selected agricultural markets. FAO, Rome, Italy.

Dercon, S. 1995. On market integration and liberalization: method and application to Ethiopia. J. Dev. Stud.32, 112-138.

Dickey DA. Fuller WA. 1979. Distribution of the estimator for autoregressive time series with a unit root. Journal of American Statistics Association, 74, 427-431.

Doldado, J. Jenkinson, T. Sosvilla-Rivero, S. (1990). Cointegration and unit roots. Journal of Economic Surveys, 4, 249-73.

Dorosh P, Ahmed H. 2009. Foreign Exchange Rationing, Wheat Markets and Food Security in Ethiopia, IFPRI and EDRI, Addis Ababa, Ethiopia.

Ethiopian Roads Authority (ERA). (2014). Assessment of 17 Years Performance Road Sector Development Program, Addis Ababa.

Food and Agriculture Organisation (FAO). (2015). FAOSTAT production database. Retrieved 05/20/2015, from http:/faostat3.fao.org/download.

Getnet K, Verbeke W, Viaene J. 2005. Modelling spatial price transmission in the grain markets of Ethiopia with an application of ARDL approach to white teff. Agricultural Economics, 33:491502.

Getnet K. 2009. Optimizing the policy cost of market stabilization: Which commodity matters most in Ethiopia? Journal of International Development, 21(3), 362-378.

International Trade Centre (ICT). 2016. http://www.trademap.org/Country [2016, 08 February].

Jaleta M, Gebermedhin B. 2009. Price Co-integration Analyses of Food Crop Markets: The case of Wheat and Teff Commodities in Northern Ethiopia. The International Association of Agricultural Economists Conference, Beijing, China; August 16-22, 2009. 
Kelbore ZG. 2013. Transmission of World Food Prices to Domestic Market: The Ethiopian Case. University of Trento.

Loening JL, Durevall D, Birru YA. 2009. Inflation Dynamics and Food Prices in an Agricultural Economy: The Case of Ethiopia, University of Gothenburg.

Mavrotas G, R. Kelly. 2001. Old Wine in New Bottles: Testing Causality between Savings and Growth, the Manchester School, 69:97-105.

Meyer, F., Westhoff, P., Binfield, J., and Kirsten, J.F. 2006. Model closure and price formation under switching grain market regimes in South Africa. Agrekon, 45(4):369-380.

Minten, B., Stifel, D., and Tamiru, S. (2012). Structural Transformation in Ethiopia: Evidence from cereal markets. Ethiopia Strategy Support Program II.

Negassa, A. Jayne, T.S. (1997). The Response of Ethiopian Grain Markets to Liberalisation. Ministry of Economic Development and Cooperation, Addis Ababa.

Negassa A, R Myers, E Gabre-Madhin. 2004. Grain Marketing Policy Changes and Spatial Efficiency of Maize and Wheat Markets in Ethiopia. International Food Policy Research Institute (IFPRI), MTDI Discussion Paper 66.

Negassa, A, Myers J.R. (2007). Estimating Policy Effects on Spatial Market Efficiency: An Extension to the Parity Bound Model. American Journal of Agricultural Economics, vol. 2, no. 89, pp. 338-352.

Perron P.1989. The great crash, the oil price shock and the unit root hypothesis. Econometrica, 57:1361-1401.

Rambaldi AN. 1997. Testing for Granger non-causality in cointegrated systems made easy’. Working Papers in Econometrics and Applied Statistics 88, Department of Econometrics, the University of New England.

Rashid S, Minot N. 2010. Are Staple Food Markets in Africa Efficient? Spatial Price Analyses and Beyond. Paper presented at the Comesa policy seminar "Food price variability: Causes, consequences, and policy options" on 25-26 January 2010 in Maputo, Mozambique. IFPRI.

Rashid S. 2011. Inter-commodity price transmission and food price policies: An analysis of Ethiopian cereal markets. The International Food Policy Research Institute (IFPRI).

Ravallion M. 1986. Testing market integration. American Journal of Agricultural Economics. 68 (1):102-109.

Regional Agricultural Trade Expansion Support Programme (RATES). 2003. Maize Market Assessment and Baseline Study for Ethiopia.

Sadoulet E., v de Janvry A. 1995. Quantitative Development Policy analysis, Johns Hopkins University Press.

Tadesse, G., and Shively, G. (2009). Food aid, food prices and producer disincentives in Ethiopia. American Journal of Agricultural Economics. 91(4):942-955.

Tamru S. 2013. Spatial integration of cereal markets in Ethiopia. Addis Ababa, Ethiopia: Ethiopia Strategy Support Program - Ethiopian Development Research Institute.

Toda HY, Yamamoto T. 1995. Statistical inference in vector auto-regressions with partially integrated processes. J. Econ. 66:225-250.

Ulimwengu JM, Workneh S, Paulosm Z. 2009. Impact of soaring food price in Ethiopia: does location matter? IFPRI.

UN comtrade. 2015. United Nations Commodity Trade Statistics database. Available: http://comtrade.un.org/db/. 
United States Department of Agriculture (USDA). 2015. Commodity database. Available: http://apps.fas.usda.gov/psdonline/psdquery.aspx [2015, 24 March].

Worku M, Jemal A, Leta T, Haji T, Legesse W, Kassa Y, Wonde A, Aschalew G, Sewagegne T, Teshale A, Tamirat B, Yoseph B, Habtamu Z. (2001). Development of Improved Maize Germplasm for the Mid and Low Altitude Sub-Humid Agro-ecologies of Ethiopia. Second National Maize Workshop of Ethiopia. 1216 November, 2001.

Zapata HO, Rambaldi AN. 1997. Monte Carlo evidence on cointegration and causation'. Oxford Bulletin of Economics and statistics, 59:285-298.

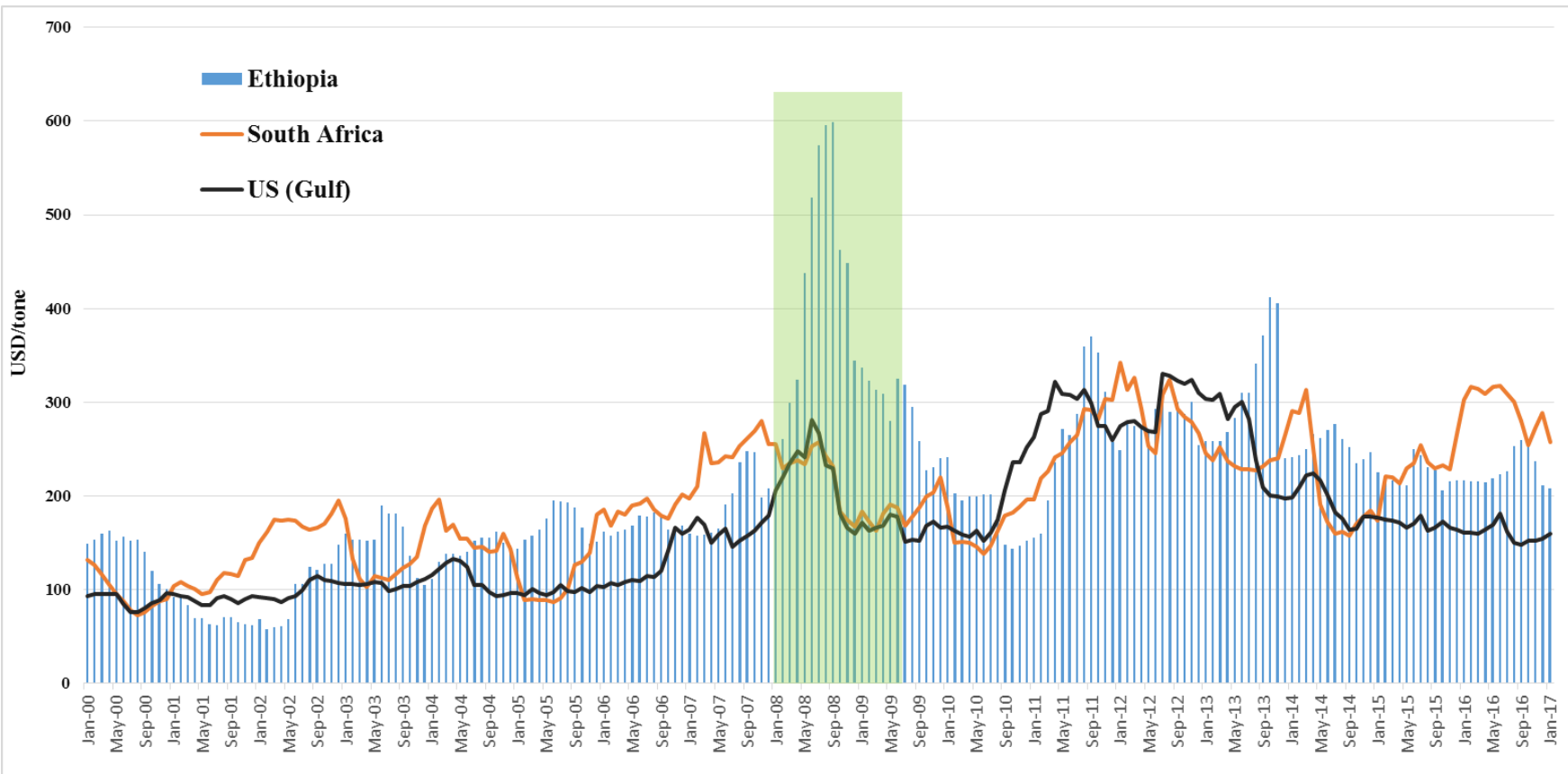

Source: FAO- (2015); International - USA: Gulf, Maize (US No. 2, Yellow); SAFEX - Randfontein, Maize (white) - Wholesale; Domestic - Ethiopia, Addis Ababa, white maize (Wholesale)

Appendix Figure 1: Domestic and international maize prices (Jan 2000 - Jan 2017) 